\title{
Hematological, biochemical, and blood gas alterations of goat whole blood stored in CPDA-1 and CPD/SAG-M plastic bags
}

\author{
Marcondes Dias Tavares ${ }^{1}$ Isabella de Oliveira Barros ${ }^{1}$ Rejane dos Santos Sousa ${ }^{1}$ \\ Paulo Ricardo Firmino ${ }^{1}$ Jucelio da Silva Gameleira ${ }^{1}$ Francisco Leonardo Costa de Oliveira $^{2}$ \\ Antonio Humberto Hamad Minervino ${ }^{*}$ (D) Enrico Lippi Ortolani ${ }^{2}$ Raimundo Alves Barrêto-Júnior ${ }^{1}$
}

\begin{abstract}
'Departamento de Ciências Animais, Universidade Federal Rural do Semiárido (UFERSA), Mossoró, RN, Brasil.
${ }^{2}$ Departamento de Clínica Veterinária, Faculdade de Medicina Veterinária e Zootecnia, Universidade de São Paulo (USP), São Paulo, SP, Brasil. ${ }^{3}$ Laboratório de Sanidade Animal (LARSANA), Universidade Federal do Oeste do Pará (UFOPA), 68040-255, Salé, Santarém, PA, Brasil. E-mail: ah.minervino@gmail.com. ${ }^{*}$ Corresponding author.
\end{abstract}

ABSTRACT: The aim of this study was to evaluate the hematological, biochemical, and blood gas alterations of goat whole blood stored in different blood bags. Seven male, adult, crossbreed goats were used, weighing $62 \pm 1.8 \mathrm{~kg}$. Nine hundred milliliters of whole blood from each animal was collected and stored in blood bags (450 $\mathrm{ml}$ in each), CPDA-1 (citrate phosphate dextrose-adenine) and CPD/SAG-M (citrate phosphate dextrose with saline-glucose-mannitol) as additive solutions, and kept refrigerated (2-4 $\left.{ }^{\circ} \mathrm{C}\right)$ for 42 days. Blood samples were collected from the plastic bags at baseline (T0) and after seven, 14, 21,28, 35, and 42 days for hematological, biochemical, blood gas, and microbiological evaluations. Free hemoglobin, degree of hemolysis, lactate, and $\mathrm{pO}_{2}$ were increased in both bags, whereas hydrogen potential $(p H)$ and the total hemoglobin concentration decreased overtime $(P<0.05)$. The red blood cell count, glucose, sodium, and potassium remained stable, compared to the baseline. The CPD/SAG-M bag presented a lower red cell count, globular volume, total hemoglobin, and sodium, and a higher degree of hemolysis and plasma hemoglobin, compared with the CPDA-1 bag. The whole goat blood remained viable for therapeutic use; although, there were some important changes in the variables of the 42-day stored blood in relation to fresh blood (T0). We concluded that the CPDA-1 bag is more suitable for use in the storage of goat blood because of its lower commercial value.

Key words: transfusion, red blood cell, hemolysis, blood therapy, goats.

Avaliação dos parâmetros hematológicos, bioquímicos e hemogasométricos do sangue caprino armazenado em bolsas CPDA-1 e CPD/SAG-M

RESUMO: O objetivo deste estudo foi avaliar as alterações hematológicas, bioquímicas e hemogasométricas do sangue total de caprinos armazenado em diferentes bolsas de sangue. Foram utilizados sete caprinos machos, adultos, sem raça definida, pesando 62 $\pm 1,8 \mathrm{~kg}$. Coletouse $900 \mathrm{~mL}$ de sangue total de cada animal, em duas bolsas plásticas tipos CPDA-1 (citrato-fosfato-dextrose-adenina) e CPD/SAG-M (citratofosfato-dextrose com solução aditiva de salina-glicose-manitol), armazenadas sob refrigeração $\left(2-4{ }^{\circ} \mathrm{C}\right)$ durante 42 dias. Amostras de sangue foram coletadas das bolsas no início do estudo (T0) e depois de sete, 14, 21, 28, 35 e 42 dias, para realização de análises hematológicas, bioquímicas, hemogasométricas e microbiológicas. Nas duas bolsas houve aumento da concentração de hemoglobina plasmática, grau de hemólise, lactato, $\mathrm{pO}_{2}$ e redução de hemoglobina total e $\mathrm{pH}(\mathrm{p}<0,05)$, porém não houve variação no número de hemácias, glicose, sódio e potássio quando comparado a momento basal (T0). A bolsa CPD/SAG-M apresentou menor número de hemácias, volume globular, concentração de hemoglobina total e sódio, e maiores valores de grau de hemólise e hemoglobina plasmática em relação a bolsa CPDA-1 $(P<0,05)$. Apesar de serem constatadas alterações em importantes variáveis do sangue caprino armazenado durante 42 dias em relação ao sangue fresco (T0), o sangue total caprino permaneceu viável para uso terapêutico. A análise comparativa entre os dois tipos de bolsa revelou uma similaridade de resultados para a grande maioria das variáveis estudadas, portanto a bolsa CPDA-1 pode ser considerada a mais indicada para uso na espécie caprina exclusivamente devido ao seu menor valor comercial.

Palavra-chave: transfusão de sangue, hemácias, hemólise, hemoterapia, caprinos.

\section{INTRODUCTION}

Brazil has a goat population of 8,8 million, $91.4 \%$ of which are raised in the northeast region (IBGE, 2015). In this region, infection by gastrointestinal nematodes, including Haemonchus contortus, is a serious health and economic problem, due to the losses caused by severe anemia and reduced weight gain (COSTA; SIMÃO; RIET-CORREA, 2011). Although, integrated parasite control is the best strategy for controlling these nematodes, when some severely infected animals have severe anemia (less than $11 \%$ globular volume), blood transfusion is required as an emergency measure to ensure survival (ARGOLO et al., 2018; SOUSA et al., 2012a).

There is an increasing interest in hemotherapy in this species, and research in veterinary 
science is being focused on expanding the knowledge related to this practice. Blood donors need to be healthy and test negative for infectious diseases, but in reality, donors who meet these requirements are not readily available (SOUSA et al., 2012b). Advances in human medicine have allowed the collection and storage of blood due to the development of preservative substances. Different blood conservation substances and methods have been researched and constantly improved in different species, in order to obtain a better quality blood product and allow a longer storage time (BALCOMB; FOSTER, 2014; LACERDA et al., 2014; REICHMANN; DEARO, 2001).

Although, some studies on blood conservation in domestic animals have been performed in cattle (RIBEIRO FILHO et al., 1994), dogs (COSTA JÚNIOR et al., 2008), horses (MUDGE et al., 2004; NIINISTO; RAEKALLIO; SANKARI, 2008), sheep (SOUSA et al., 2013) and buffalo (NUNES NETO et al., 2018), blood conservation in goats has only been evaluated empirically in veterinary medicine. A study evaluating blood transfusion in goats showed no difference in lipid peroxidation, liver function, and renal function, regardless of whether fresh or stored whole blood was used for transfusion (FONSECA et al., 2018).

There are different blood bags available on the market, depending on the solvent used. The citrate phosphate dextrose-adenine (CPDA-1) bag is the most commonly used and the most affordable, preserving human blood for 35 days. There are more expensive bags with additive solutions such as citrate phosphate dextrose containing saline glucose mannitol (CPD/SAG-M), in which blood is conserved longer (SOUSA et al., 2013).

Veterinary transfusion medicine will benefit from an evaluation of the changes during storage of blood products in different blood bags (different solvents' benefits), under various conservation methods, while considering the particularities of each species. Such knowledge will allow the appropriate therapeutic use of blood and its components. This study aimed to evaluate the possible changes in the hematological, biochemical and blood gas parameters of goat whole blood during 42 days storage in CPDA1 and CPD/SAG-M bags and to compare the quality of the blood stored in the two types of bags.

\section{MATERIALS AND METHODS}

Seven male castrated adult goats of no defined breed, weighing $62 \pm 1.8 \mathrm{~kg}$, were used. From each animal $15 \mathrm{ml} / \mathrm{kg}$ of blood was sampled and placed in two $450 \mathrm{~mL}$ plastic bags: citrate phosphate dextrose-adenine: CPDA-1 bag (Fresenius Hemocare ${ }^{\circledR}$, Fresenius Kabi Brazil Ltda., Barueri, SP, Brazil), and citrate phosphate dextrose with saline glucose mannitol: CPD/SAG-M bag (Fresenius Hemocare $^{\circledR}$, Fresenius Kabi Brazil Ltda., Barueri, SP, Brazil). Prior to collection, the puncture area over the jugular vein was shaved and aseptically prepared (MARCHI et al., 2018). Both samples were collected simultaneously by external jugular vein venipuncture; they were homogenized and weighed using a digital scale (Model BN, Coimma ${ }^{\circledR}$ Farming Ltd, Dracena, SP, Brazil). One milliliter of blood was considered to be equivalent to one gram. The bags were stored in a refrigerator for 42 days and kept at an average temperature of $3{ }^{\circ} \mathrm{C}$, being homogenized once a day. The stored blood was evaluated weekly, by measuring the hematological, biochemical, blood gas and microbiological parameters, at seven times (T): T0 (immediately after collection, baseline), at T7 (seven days), at T14 (fourteen days), at T21 (twenty one days), at T28 (twenty eight days), at T35 (thirty five days) and at T42 (forty two days after collection).

Hematological evaluation consisted of the determination of the globular volume $(\mathrm{GV})$, the red blood cell count, the leukocytes count, the total and free hemoglobin concentrations, the mean corpuscular volume (MCV) and the determination of the degree of hemolysis according to the classical methodology (WEISS; WARDROP; WEISS, 2011). Red blood cell and leukocyte counts were performed using manual cell counting macro dilution method with Neubauer chamber. The globular volume was measured by centrifuging the whole blood in capillary tubes and manual reading. The total and free hemoglobin concentrations were determined by the cyanmethemoglobin method with a spectrophotometric reading subsequently at 540 nm (Quimis Aparelhos Científicos Ltda, Diadema, SP, Brazil). Degree of hemolysis was calculated according to the formula: Degree of hemolysis (\%) $=(100$-globular volume $) \mathrm{x}$ free hemoglobin $(\mathrm{g} / \mathrm{dl}) /$ total hemoglobin (g/dl) (MUDGE et al., 2004).

Biochemical variables measured in plasma were the total protein, glucose, lactate, sodium and potassium. Plasma glucose, lactate and the total protein concentrations were determined using commercial kits on an automated biochemical analyzer (Model Rx Daytona, Randox ${ }^{\circledR}$, Crumlin, UK). Sodium and potassium plasma concentrations were determined by flame photometry (KORZUN; MILLER, 2010), using a flame photometer (model FC-130, CELM ${ }^{\circledR}$, Barueri, SP, Brazil). 
Blood gas analysis was performed using a portable blood gas analyzer (i-STAT, Abbott Point Care $^{\circledR}$, Chicago, IL, USA) with specific commercial cartridges (CG4+, Abbott Point $\mathrm{Care}^{\circledR}$, Chicago, IL, USA) at each time. Variables measured were: hydrogen potential $(\mathrm{pH})$, partial pressure of oxygen $\left(\mathrm{pO}_{2}\right)$, partial pressure carbon dioxide $\left(\mathrm{pCO}_{2}\right)$, oxygen saturation $\left(\mathrm{sO}_{2}\right)$, bicarbonate $\left(\mathrm{HCO}_{3}\right)$, base excess (BE) and total carbon dioxide $\left(\mathrm{TCO}_{2}\right)$.

For the microbiological evaluation, aliquots of blood were seeded in Petri dishes containing blood agar culture medium (Blood Agar Base added with 5\% sheep blood). The Petri dishes were then placed in an oven at $36{ }^{\circ} \mathrm{C}$ for 48 hours and then analyzed for bacterial growth using a colony counter (ARAÚJO, 2012).

Data were submitted to the KolmogorovSmirnov test. Two-way repeated measurement ANOVA followed by the Bonferroni mean comparison test was used, since the data had normal distribution. Data analysis were made with Prism statistical software (GraphPad Software Inc., San Diego, CA, USA), adopting a significance level of 5\%.

\section{RESULTS}

The main results of the hematological, biochemical and blood gas evaluations are presented in tables 1, 2 and 3, respectively. It was difficult to compare several variables due to the difference in blood bags volume, which diluted the plasma components, as the CPD/SAG-M bag had a total of $163 \mathrm{ml}$ of preservative solution, while CPDA-1 had only $63 \mathrm{ml}$.

The red blood cell count, $\mathrm{GV}$ and $\mathrm{MCV}$ did not differ between the baseline (T0) and the other times in either bag $(\mathrm{P}>0.05)$. There was no difference in the leukocyte counts over time in the CPDA-1 bag, while in the CPD/SAG-M bag, there was a reduction at T42 compared with the baseline $(\mathrm{P}<0.05)$.

There was a gradual reduction in the total hemoglobin concentration during storage, with a difference $(\mathrm{P}<0.05)$ from baseline observed from $\mathrm{T} 21$ and onwards and from T28 and onwards in the CPDA1 and CPD/SAG-M bags, respectively. This reduction corresponded to $17.3 \%$ in CPDA-1 and $14.8 \%$ in CPD/SAG-M, comparing T42 with the baseline. Regarding free hemoglobin concentrations, there was an increase $(\mathrm{P}<0.05)$ in relation to baseline from $\mathrm{T} 7$ and onwards for CPDA-1 bag, reaching values three times higher baseline at T42. In the CPD/SAG-M bag, increase started at T14 and reached $26.7 \%$ at T42 in comparison to baseline. The values of the degree of hemolysis increased $(\mathrm{P}<0.05)$ from $\mathrm{T} 7$ and onwards for the CPDA-1 bag and from T14 and onwards for the CPD/SAG-M bag, compared to the baseline (T0). The CPD/SAG-M bags had higher values $(\mathrm{P}<0.05)$ of free hemoglobin than CPDA-1.

There was no difference observed between the plasma glucose and the sodium values of the two bags. However, higher potassium values $(\mathrm{P}<0.05)$ were observed from $\mathrm{T} 7$ and onwards on $\mathrm{CPD} / \mathrm{SAG}-\mathrm{M}$ and from T14 and onwards on CPDA-1 compared to the baseline. Higher plasma lactate concentrations $(\mathrm{P}<0.05)$ were found at $\mathrm{T} 21$ and onward in relation to the baseline of both bags, with an increase of $59 \%$ and $40 \%$ in the CPDA- 1 and CPD/SAG-M bags, respectively. Total protein had lower mean values $(\mathrm{P}<0.05)$ only at $\mathrm{T} 42$ compared to the baseline in both bags, with a decrease of $6.6 \%$ in the CPDA- 1 bag and $7.8 \%$ in the CPD/SAG-M bag.

The $\mathrm{pH}$ values showed similar changes in both bags, being lower than the baseline at all times $(\mathrm{P}<0.05)$; however, this reduction was only $0.72 \%$ in the CPDA-1 bag and $1.1 \%$ in CPD/SAG-M bag, compared to the baseline values. The $\mathrm{pCO}_{2}$ remained without a difference between the baseline and the other times for both bags ( $\mathrm{p}>0.05)$.

Higher $\mathrm{pO}_{2}$ values $(\mathrm{P}<0.05)$ were recorded from T21 until T42 in relation to both bags' baselines, with increases up to $342 \%$ at T42 for the CPDA-1 bag, and $337 \%$ for the CPD/SAG-M bag. The plasma $\mathrm{HCO}_{3}$ values $(\mathrm{P}<0.05)$ decreased at $\mathrm{T} 42$ only in relation to $\mathrm{T} 0$ for both bags. $\mathrm{TCO}_{2}$ values decreased only at T35 and at T42, when compared to T0 for the CPDA-1 bag $(\mathrm{P}<0.05)$, and there was no difference between T0 and the other times for the CPD/SAG-M bag $(\mathrm{P}>0.05)$.

From $\mathrm{T} 14$ onwards, $\mathrm{sO}_{2}$ values were higher than the baseline for both bags $(\mathrm{P}<0.05)$ and this increase was $47.8 \%$ at T42 for the CPDA- 1 bag, and $30.2 \%$ for the CPD/SAG-M bag. The BE increased from T21 and onwards and from T7 and onwards for the CPDA-1 and CPD/SAG-M bags, respectively.

All sample cultures performed during the experimental period were negative for bacterial growth in both bags.

\section{DISCUSSION}

Red blood cell count, GV and MCV did not differ significantly during the storage period in either bag, suggesting that the components of the bags used were effective in maintaining the integrity of these cells. However, studies with sheep (SOUSA et al., 2013) and buffalo blood (NUNES NETO et al., 2018) 
Table 1 - Mean values and standard deviations of hematological variables of goat whole blood stored in CPDA-1 (citrate phosphate dextrose adenine) CPD/SAG-M (citrate phosphate dextrose with saline-glucose-mannitol).

\begin{tabular}{|c|c|c|c|c|c|c|c|c|}
\hline \multirow[t]{2}{*}{ Variables } & \multicolumn{8}{|c|}{--1-- } \\
\hline & & T0 & $\mathrm{T} 7$ & $\mathrm{~T} 14$ & $\mathrm{~T} 21$ & $\mathrm{~T} 28$ & T35 & $\mathrm{T} 42$ \\
\hline \multirow{2}{*}{ Red Blood cells $\left(\times 10^{6}\right)$} & $\mathrm{C}$ & $12 ., 7 \pm 1,4$ & $12,9 \pm 1,6^{\mathrm{A}}$ & $12,2 \pm 1,3^{\mathrm{A}}$ & $13,8 \pm 2,4^{\mathrm{A}}$ & $13,3 \pm 1,8^{\mathrm{A}}$ & $13,1 \pm 1,7^{\mathrm{A}}$ & $13,5 \pm 1,9^{\mathrm{A}}$ \\
\hline & $\mathrm{S}$ & $12,6 \pm 2,5$ & $10,9 \pm 1,3^{\mathrm{B}}$ & $10,6 \pm 1,1^{\mathrm{B}}$ & $11,4 \pm 1,7^{\mathrm{B}}$ & $10,9 \pm 1,0^{\mathrm{B}}$ & $11,2 \pm 1,2^{\mathrm{B}}$ & $11,6 \pm 2,1^{\mathrm{B}}$ \\
\hline \multirow{2}{*}{ GV $(\%)$} & $\mathrm{C}$ & $20,2 \pm 1,6$ & $21,0 \pm 1,9^{\mathrm{A}}$ & $20,8 \pm 2,2^{\mathrm{A}}$ & $21,2 \pm 2,2^{\mathrm{A}}$ & $20,7 \pm 1,6^{\mathrm{A}}$ & $21,8 \pm 2,1^{\mathrm{A}}$ & $21,4 \pm 3,9^{\mathrm{A}}$ \\
\hline & $\mathrm{S}$ & $18,2 \pm 3,4$ & $17,5 \pm 1,9^{\mathrm{B}}$ & $17,1 \pm 1,4^{\mathrm{B}}$ & $17,2 \pm 1,3^{\mathrm{B}}$ & $17,1 \pm 1,4^{\mathrm{B}}$ & $16,7 \pm 1,5^{\mathrm{B}}$ & $18,1 \pm 1,7^{\mathrm{B}}$ \\
\hline \multirow{2}{*}{ MCV (fL) } & $\mathrm{C}$ & $16,0 \pm 0,9$ & $16,2 \pm 1,1$ & $17,0 \pm 1,2$ & $15,6 \pm 1,7$ & $15,7 \pm 1,2$ & $16,7 \pm 1,1$ & $15,8 \pm 1,4$ \\
\hline & $\mathrm{S}$ & $15,2 \pm 2,8$ & $16,3 \pm 2,6$ & $16,3 \pm 2,2$ & $15,5 \pm 2,6$ & $15,9 \pm 2,0$ & $15,0 \pm 2,2$ & $15,9 \pm 3,4$ \\
\hline \multirow{2}{*}{ White blood cells $\left(\times 10^{3}\right)$} & $\mathrm{C}$ & $6,47 \pm 2,4$ & $8,10 \pm 2,4$ & $6,89 \pm 2,6$ & $7,34 \pm 1,96$ & $6,46 \pm 1,21$ & $6,25 \pm 2,7$ & $6,15 \pm 2,6$ \\
\hline & $\mathrm{S}$ & $6,29 \pm 1,7^{\mathrm{a}}$ & $6,71 \pm 2,2^{\mathrm{a}}$ & $6,09 \pm 1,7^{\mathrm{a}}$ & $5,34 \pm 1,9^{\mathrm{a}}$ & $3,86 \pm 1,7^{\mathrm{a}}$ & $4,31 \pm 2,3^{\mathrm{a}}$ & $3,69 \pm 1,9^{b}$ \\
\hline \multirow{2}{*}{ Total Hg (g/dL) } & $\mathrm{C}$ & $7,7 \pm 0,6^{\mathrm{Aa}}$ & $7,6 \pm 0,5^{\mathrm{Aa}}$ & $7,4 \pm 0,5^{\mathrm{Aa}}$ & $7,2 \pm 0,5^{\mathrm{Ab}}$ & $7,0 \pm 0,5^{\mathrm{Ab}}$ & $7,1 \pm 0,5^{\mathrm{Ab}}$ & $6,3 \pm 0,6^{\mathrm{Ab}}$ \\
\hline & $\mathrm{S}$ & $6,2 \pm 0,4^{\mathrm{Ba}}$ & $6,2 \pm 0,5^{\mathrm{Ba}}$ & $6,1 \pm 0,4^{\mathrm{Ba}}$ & $6,0 \pm 0,4^{\mathrm{Ba}}$ & $5,9 \pm 0,4^{\mathrm{Bb}}$ & $5,7 \pm 0,4^{\mathrm{Bb}}$ & $5,3 \pm 0,4^{\mathrm{Bb}}$ \\
\hline \multirow{2}{*}{ Free $\mathrm{Hg}^{*}(\mathrm{~g} / \mathrm{dL})$} & $\mathrm{C}$ & $0,004^{\mathrm{a}}$ & $0,005^{\mathrm{Ab}}$ & $0,006^{\mathrm{Ab}}$ & $0,009^{\mathrm{Ab}}$ & $0,011^{\mathrm{Ab}}$ & $0,011^{\mathrm{Ab}}$ & $0,012^{\mathrm{Ab}}$ \\
\hline & $\mathrm{S}$ & $0,011^{\mathrm{Ba}}$ & $0,011^{\mathrm{Ba}}$ & $0,012^{\mathrm{Bb}}$ & $0,014^{\mathrm{Bb}}$ & $0,014^{\mathrm{Bb}}$ & $0,015^{\mathrm{Bb}}$ & $0,015^{\mathrm{Bb}}$ \\
\hline \multirow{2}{*}{ Degree of hemolysis ${ }^{*}(\%)$} & $\mathrm{C}$ & $0,04^{\mathrm{Aa}}$ & $0,05^{\mathrm{Ab}}$ & $0,07^{\mathrm{Ab}}$ & $0,09^{\mathrm{Ab}}$ & $0,12^{\mathrm{Ab}}$ & $0,12^{\mathrm{Ab}}$ & $0,13^{\mathrm{Ab}}$ \\
\hline & $\mathrm{S}$ & $0,14^{\mathrm{Ba}}$ & $0,14^{\mathrm{Ba}}$ & $0,16^{\mathrm{Bb}}$ & $0,18^{\mathrm{Bb}}$ & $0,19^{\mathrm{Bb}}$ & $0,21^{\mathrm{Bb}}$ & $0,21^{\mathrm{Bb}}$ \\
\hline
\end{tabular}

Means with different lowercase letters on the same line differ from each other (intragroup comparison in time) (P <0.05). Means with different capital letters in the same column differ from each other (comparison between bags at each time) $(\mathrm{P}<0.05)$. ${ }^{*}$ Variables with standard deviation equal to or less than 0.02 and not shown in the table. C: CPDA-1; S: SAG-M; GV: globular volume; MCV: mean corpuscular volume; $\mathrm{Hg}$ : hemoglobin.

stored in CPDA-1 bags, showed a reduction in the red blood cell count, followed by a reduction in GV and an increase in $\mathrm{MCV}$, thus indicating red cell lysis or engorgement, unlike what we observed in goat red cells. Leukocyte count did not change in the CPDA-1 bag, but there was a sharp reduction of it in the CPD/
SAG-M bag. Leukocytes have a shorter lifespan than red blood cells and when apoptosis occurs, these cells release several enzymes that can affect the red blood cell membrane, together with several proinflammatory cytokines (interleukins 6,8 ) and the tumor necrosis factor $\alpha$, which can also aggravate

Table 2 - Mean values and standard deviations of biochemical variables of goat whole blood stored in CPDA-1 (citrate phosphate dextrose-adenine) and CPD/SAG-M (citrate phosphate dextrose with saline-glucose-mannitol).

\begin{tabular}{|c|c|c|c|c|c|c|c|c|}
\hline \multirow[t]{2}{*}{ Variables } & \multicolumn{8}{|c|}{ 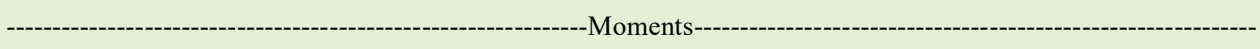 } \\
\hline & & T0 & $\mathrm{T} 7$ & T14 & $\mathrm{T} 21$ & $\mathrm{~T} 28$ & T35 & T42 \\
\hline \multirow{2}{*}{ Glucose (mg/dL) } & $\mathrm{C}$ & $573.3 \pm 35.7$ & $582.0 \pm 34.5$ & $586.1 \pm 36.4$ & $575.2 \pm 42.9$ & $550.6 \pm 37.2$ & $558.9 \pm 43.2$ & $558.8 \pm 45.9$ \\
\hline & $\mathrm{S}$ & $588.8 \pm 75.2$ & $575.2 \pm 28.4$ & $568.0 \pm 27.7$ & $558.2 \pm 38.9$ & $558.4 \pm 39.0$ & $553.3 \pm 37.0$ & $549.5 \pm 45.7$ \\
\hline \multirow{2}{*}{ Lactate $(\mathrm{g} / \mathrm{dL})$} & $\mathrm{C}$ & $39.9 \pm 28.2^{\mathrm{a}}$ & $42.9 \pm 28.4^{\mathrm{a}}$ & $45.4 \pm 28.3^{\mathrm{a}}$ & $49.7 \pm 28.1^{b}$ & $52.8 \pm 29.2^{\mathrm{b}}$ & $58.2 \pm 28.3^{\mathrm{b}}$ & $63.5 \pm 29.4^{\mathrm{b}}$ \\
\hline & $\mathrm{S}$ & $29.4 \pm 14.3^{\mathrm{a}}$ & $34.6 \pm 23.5^{\mathrm{a}}$ & $36.2 \pm 22.4^{\mathrm{a}}$ & $39.0 \pm 23.1^{\mathrm{b}}$ & $42.3 \pm 23.2^{\mathrm{b}}$ & $46.2 \pm 24.5^{\mathrm{b}}$ & $49.6 \pm 24.2^{\mathrm{b}}$ \\
\hline \multirow{2}{*}{$\mathrm{TP}(\mathrm{mg} / \mathrm{dL})$} & $\mathrm{C}$ & $8.06 \pm 0.3^{\mathrm{Aa}}$ & $8.11 \pm 0.3^{\mathrm{Aa}}$ & $8.14 \pm 0.3^{\mathrm{Aa}}$ & $8.20 \pm 0.3^{\mathrm{Aa}}$ & $8.51 \pm 0.4^{\mathrm{Aa}}$ & $8.09 \pm 0.6^{\mathrm{Aa}}$ & $7.53 \pm 0.7^{\mathrm{Ab}}$ \\
\hline & $\mathrm{S}$ & $7.09 \pm 0.5^{\mathrm{Ba}}$ & $6.81 \pm 0.3^{\mathrm{Ba}}$ & $6.77 \pm 0.2^{\mathrm{Ba}}$ & $6.96 \pm 0.2^{\mathrm{Ba}}$ & $7.06 \pm 0.1^{\mathrm{Ba}}$ & $7.06 \pm 0.2^{\mathrm{Ba}}$ & $6.54 \pm 0.4^{\mathrm{Bb}}$ \\
\hline \multirow{2}{*}{ Sodium $(\mathrm{mEq} / \mathrm{L})$} & $\mathrm{C}$ & $166.6 \pm 8.6^{\mathrm{A}}$ & $166.6 \pm 4.6$ & $164.6 \pm 4.7^{\mathrm{A}}$ & $166.0 \pm 5.2^{\mathrm{A}}$ & $159.4 \pm 9.3$ & $162.3 \pm 3.9^{\mathrm{A}}$ & $161.4 \pm 10^{\mathrm{A}}$ \\
\hline & $\mathrm{S}$ & $152.6 \pm 12^{\mathrm{B}}$ & $159.4 \pm 3.8$ & $153.4 \pm 2.2^{\mathrm{B}}$ & $153.1 \pm 1.6^{\mathrm{B}}$ & $150.0 \pm 3.8$ & $150.6 \pm 2.8^{\mathrm{B}}$ & $145.4 \pm 6.8^{\mathrm{B}}$ \\
\hline \multirow{2}{*}{ Potassium (mEq/L) } & $\mathrm{C}$ & $4.2 \pm 0.4^{\mathrm{a}}$ & $5.4 \pm 1.12^{\mathrm{b}}$ & $7.6 \pm 1.8^{\mathrm{b}}$ & $7.5 \pm 1.5^{b}$ & $9.0 \pm 2.8^{\mathrm{b}}$ & $9.3 \pm 2.6^{\mathrm{b}}$ & $9.4 \pm 3.0^{\mathrm{b}}$ \\
\hline & $\mathrm{S}$ & $3.3 \pm 0.2^{\mathrm{a}}$ & $4.9 \pm 0.8^{\mathrm{a}}$ & $6.1 \pm 1.7^{\mathrm{b}}$ & $6.8 \pm 1.7^{\mathrm{b}}$ & $7.2 \pm 1.4^{\mathrm{b}}$ & $7.6 \pm 2.3^{b}$ & $7.8 \pm 2.3^{b}$ \\
\hline
\end{tabular}

Means with different lowercase letters on the same line differ from each other (intragroup comparison with time) $(\mathrm{P}<0.05)$. Means with different capital letters in the same column differ from each other (comparison between bags at each time) $(\mathrm{P}<0.05)$. TP: Total Protein; $\mathrm{C}$ : CPDA-1; S: SAG-M. 
Table 3 - Mean values and standard deviations of blood gas variables of goat whole blood stored in CPDA-1 (citrate phosphate dextrose adenine) and CPD/SAG-M (citrate phosphate dextrose with additive saline-glucose-mannitol).

\begin{tabular}{|c|c|c|c|c|c|c|c|c|}
\hline \multirow[t]{2}{*}{ Variables } & \multicolumn{8}{|c|}{ 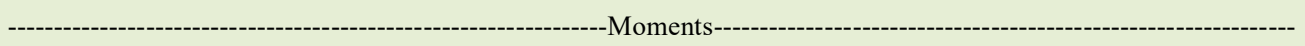 } \\
\hline & & T0 & $\mathrm{T} 7$ & $\mathrm{~T} 14$ & $\mathrm{~T} 21$ & T28 & T35 & $\mathrm{T} 42$ \\
\hline \multirow{2}{*}{$\mathrm{pH}$} & $\mathrm{C}$ & $6.91 \pm 0.04^{\mathrm{a}}$ & $6.86 \pm 0.04^{\mathrm{b}}$ & $6.86 \pm 0.04^{\mathrm{b}}$ & $6.86 \pm 0.04^{\mathrm{b}}$ & $6.88 \pm 0.04^{\mathrm{a}}$ & $6.86 \pm 0.05^{\mathrm{b}}$ & $6.86 \pm 0.06^{\mathrm{b}}$ \\
\hline & $\mathrm{S}$ & $6.94 \pm 0.04^{\mathrm{a}}$ & $6.89 \pm 0.05^{\mathrm{b}}$ & $6.87 \pm 0.05^{\mathrm{b}}$ & $6.88 \pm 0.05^{\mathrm{b}}$ & $6.86 \pm 0.05^{\mathrm{b}}$ & $6.86 \pm 0.05^{\mathrm{b}}$ & $6.86 \pm 0.06^{\mathrm{b}}$ \\
\hline \multirow{2}{*}{$\mathrm{pCO}_{2}(\mathrm{mmHg})$} & $\mathrm{C}$ & $87.7 \pm 11.0^{\mathrm{A}}$ & $95.7 \pm 12.6^{\mathrm{A}}$ & $97.0 \pm 10.7^{\mathrm{A}}$ & $93.4 \pm 11.2^{\mathrm{A}}$ & $87.9 \pm 8.2^{\mathrm{A}}$ & $82.9 \pm 17.3^{\mathrm{A}}$ & $84.5 \pm 11.7^{\mathrm{A}}$ \\
\hline & $\mathrm{S}$ & $68.5 \pm 9.4^{\mathrm{B}}$ & $75.1 \pm 10.1^{\mathrm{B}}$ & $79.4 \pm 10.5^{\mathrm{B}}$ & $74.7 \pm 10.4^{\mathrm{B}}$ & $79.8 \pm 10.8^{\mathrm{A}}$ & $77.0 \pm 8.5^{\mathrm{A}}$ & $75.8 \pm 11.4^{\mathrm{A}}$ \\
\hline \multirow{2}{*}{$\mathrm{pO}_{2}(\mathrm{mmHg})$} & $\mathrm{C}$ & $68.7 \pm 12.9^{\mathrm{a}}$ & $77.9 \pm 20.7^{\mathrm{a}}$ & $104.7 \pm 38.2^{\mathrm{a}}$ & $124.4 \pm 71.8^{\mathrm{b}}$ & $190.3 \pm 43.5^{b}$ & $221.4 \pm 27.9^{b}$ & $235.4 \pm 13.3^{b}$ \\
\hline & $\mathrm{S}$ & $67.1 \pm 9.5^{\mathrm{a}}$ & $78.0 \pm 8.6^{\mathrm{a}}$ & $95.6 \pm 22.8^{\mathrm{a}}$ & $131.9 \pm 38.0^{\mathrm{b}}$ & $159.6 \pm 54.3^{\mathrm{b}}$ & $201.7 \pm 48^{\mathrm{b}}$ & $226.7 \pm 26.7^{b}$ \\
\hline \multirow{2}{*}{$\mathrm{HCO}_{3}(\mathrm{mmol} / \mathrm{L})$} & $\mathrm{C}$ & $6.47 \pm 2.37$ & $8.10 \pm 2.43$ & $6.89 \pm 2.62$ & $7.34 \pm 1.96$ & $6.46 \pm 1.2$ & $6.25 \pm 2.7$ & $6.15 \pm 2.55$ \\
\hline & $\mathrm{S}$ & $6.29 \pm 1.86^{\mathrm{a}}$ & $6.71 \pm 2.18^{\mathrm{a}}$ & $6.09 \pm 1.74^{\mathrm{a}}$ & $5.34 \pm 1.97^{\mathrm{a}}$ & $3.86 \pm 1.7^{\mathrm{a}}$ & $4.31 \pm 2.3^{\mathrm{a}}$ & $3.69 \pm 1.91^{\mathrm{b}}$ \\
\hline \multirow{2}{*}{$\mathrm{TCO}_{2}(\mathrm{mmol} / \mathrm{L})$} & $\mathrm{C}$ & $19.2 \pm 2.6^{\mathrm{a}}$ & $19.2 \pm 2.4^{\mathrm{Aa}}$ & $19.4 \pm 2.2^{\mathrm{a}}$ & $18.7 \pm 2.6^{\mathrm{Aa}}$ & $18.0 \pm 1.9^{\mathrm{a}}$ & $17.5 \pm 2.2^{\mathrm{b}}$ & $16.8 \pm 2.1^{\mathrm{b}}$ \\
\hline & $\mathrm{S}$ & $16.1 \pm 2.1^{\mathrm{a}}$ & $15.7 \pm 1.9^{\mathrm{B} \mathrm{a}}$ & $16.2 \pm 2.2^{\mathrm{a}}$ & $15.4 \pm 2.0^{\mathrm{B} \mathrm{a}}$ & $15.7 \pm 1.9^{\mathrm{a}}$ & $15.1 \pm 1.8^{\mathrm{a}}$ & $15.1 \pm 2.3^{\mathrm{a}}$ \\
\hline \multirow{2}{*}{$\mathrm{SO}_{2}(\mathrm{mmol} / \mathrm{L})$} & $\mathrm{C}$ & $66.86 \pm 8.8^{\mathrm{a}}$ & $71.14 \pm 9.4^{\mathrm{a}}$ & $82.7 \pm 8.7^{b}$ & $91 \pm 6.6^{b}$ & $97.14 \pm 2.8^{b}$ & $98.57 \pm 0.7^{b}$ & $98.86 \pm 0.3^{b}$ \\
\hline & $\mathrm{S}$ & $68.71 \pm 8.9^{\mathrm{a}}$ & $74.43 \pm 6.5^{\mathrm{a}}$ & $81 \pm 10.3^{b}$ & $91 \pm 6.4^{b}$ & $93.14 \pm 7.2^{b}$ & $97.14 \pm 3.3^{b}$ & $98.43 \pm 0.7^{b}$ \\
\hline \multirow{2}{*}{$\mathrm{BE}$} & $\mathrm{C}$ & $-15.7 \pm 2.5^{\mathrm{a}}$ & $-16.6 \pm 2.5^{\mathrm{a}}$ & $-16.5 \pm 2.5^{\mathrm{a}}$ & $-16.86 \pm 2.4^{b}$ & $-17.2 \pm 2.5^{b}$ & $-18.0 \pm 2.8^{b}$ & $-18.5 \pm 2.5^{b}$ \\
\hline & $\mathrm{S}$ & $-17.7 \pm 2.2^{\mathrm{a}}$ & $-18.7 \pm 2.2^{b}$ & $-18.7 \pm 2.2^{b}$ & $-19.5 \pm 2.3^{b}$ & $-19.4 \pm 2.4^{b}$ & $-20.1 \pm 2.5^{b}$ & $-20.4 \pm 2.5^{b}$ \\
\hline
\end{tabular}

Means with different lowercase letters on the same line differ from each other (intragroup comparison with time) $(\mathrm{P}<0.05)$. Means with different capital letters in the same column differ from each other (comparison between bags at each time) $(\mathrm{P}<0.05)$. $\mathrm{pH}$ : hydrogen potential; $\mathrm{pCO}_{2}$ : carbon dioxide pressure; $\mathrm{pO}_{2}$ : oxygen potential; $\mathrm{HCO}_{3}$ : bicarbonate; $\mathrm{TCO}_{2}$ : total carbon dioxide; $\mathrm{SO}$ : oxygen saturation; BE: base excess; C: CPDA-1; S: SAG-M.

the existing inflammatory processes. During storage, leukocytes utilize nutrients from the preservative solution, reducing the nutrient availability to red blood cells, as observed in human and canine blood (CORSI et al., 2014; LANEVSCHI; WARDROP, 2001; MCMICHAEL et al., 2010). Reduction in leukocyte count in the CPD/SAG-M bags was accompanied by an increase of free hemoglobin and degree of hemolysis, which may indicate that leukocytes-released enzymes may have affected the red blood cell membrane (MCMICHAEL, et al., 2010). However, in order to validate this hypothesis, further studies are needed, evaluating the blood conservation after leukocyte reduction.

Reduction in the total hemoglobin differed from similar studies in other species, which reported no significant change in the total hemoglobin concentration (NIINIST; RAEKALLIO; SANKARI, 2008), while at the same time corroborated with previous findings in cattle (RIBEIRO FILHO et al., 1994). We observed an increase in the plasma hemoglobin in our study, which was also described in other studies (NUNES NETO et al., 2018; SOUSA et al., 2013), and this increase was commonly attributed to the release of the hemoglobin into the plasma as red blood cells rupture, or simply to detaching vesicles from the cell surface with hemoglobin inside (HESS; GREENWALT, 2002). The highest value of hemoglobin obtained in both types of bags was $0.015 \mathrm{~g} / \mathrm{dl}$, which was below the recommended value for conserved human blood: not less than $0.2 \mathrm{~g} / \mathrm{dl}$ (ANVISA, 2004).

Hemolysis is a common event during blood storage; however, the hemolysis values must be within a safe range. In this study, there was an increase in the degree of hemolysis subsequent to the baseline for both bags. However, the highest hemolysis value obtained in this study was $0.21 \%$ (CPD/SAG-M ), which was below those reported in studies with other species (NIINISTO; RAEKALLIO; SANKARI, 2008), and also far below the limit values for the use of stored human blood (0.8\% Europe and 1.0\% Brazil and the United States), thus showing the quality of blood storage used in this study (ANVISA, 2004).

There was no registered difference in the glucose concentration throughout the whole time for both bags. However, blood conservation studies in donkeys and sheep, showed a marked decrease in the concentration of this variable in the CPDA-1and the CPD/SAG-M bags for donkeys (BARROS, 2011) and in the CPD/SAG-M bags for sheep (SOUSA et al., 2013). The glucose concentration tends to decrease 
during storage as it is being used as an energy source for ATP production. Failure to observe a decrease in the glucose values may be associated with either low consumption by goat red blood cells when compared to other species, or higher ATP reserve in goat red blood cells (KANEKO; HARVEY; BRUSS, 2008).

Inversion of the initial sodium and potassium concentrations is a frequent finding in blood conservation studies: blood plasma sodium value decreases and potassium value increase, as observed in sheep and donkeys stored blood (BARROS, 2011; SOUSA et al., 2013). However, sodium ions concentrations did not vary in our study, and potassium ions increased in much smaller proportions, compared to the aforementioned reports. These results align with the variables red blood cells count, MCV and low percentage of hemolysis, indicating the good functioning of the preserved goat red blood cell membrane in stored blood.

Blood $\mathrm{pH}$ values usually decrease immediately upon storage in blood bags due to the $\mathrm{pH}$ of the preservative solutions, as studied samples show. It may be due to the red blood cells anaerobic metabolism, where acid metabolites accumulate during the blood storage process (RIBEIRO FILHO et al., 1994). In our study, the maximum decrease of blood $\mathrm{pH}$ was $1.2 \%$ in relation to the baseline, while it ranged from $4.4 \%$ to $8.7 \%$ in studies with other species, (NUNES NETO et al., 2018; SOUSA, et., 2012) showing great conservation capacity of the goat blood with minimal deleterious changes.

The $\mathrm{pCO}_{2}$ increase occurs due to the lactic acid buffering, produced by cellular metabolism. The lack of variation in $\mathrm{pCO}_{2}$ values between $\mathrm{T} 0$ and other times, suggests escape of $\mathrm{CO}_{2}$ by diffusion through the plastic bag wall, since stored cells do not stop $\mathrm{CO}_{2}$ production (HESS, 2010). The $\mathrm{pO}_{2}$ increase could be attributed to the oxygen passing from the external environment to the interior of the bags, as the bags are permeable to blood gases. RIBEIRO FILHO et al. (1994) proposed this mechanism in their studies with bovine blood stored in CPDA-1 bags. The $\mathrm{pO}_{2}$ increase contributed decisively to the observed increase in oxygen saturation. The oxygen affinity for hemoglobin is represented on the hemoglobin dissociation curve, where the partial oxygen pressure values, correspond to the oxygen saturation values (CARLSON, 1997).

Lactate increased at T21 and onwards in both bags. This metabolite increase was documented in other species studies (BARROS, 2011) and is due to the glucose utilization by cells. Bicarbonate is a weak base, responsible for over $50 \%$ of the buffering capacity of the extracellular medium. However, the decrease in plasma bicarbonate values was observed at T42 and in much lower proportions than the lactate values increased. This finding showed that bicarbonate is not the main lactate buffer during blood storage, considering the little $\mathrm{pH}$ decrease. Baseline $\mathrm{BE}$ values showed the initial preservative solution acidity. Increased acidity observed during goat blood storage stayed within normal range (KANEKO; HARVEY; BRUSS, 2008). This observation showed the stabilization capacity of the goat blood, stored in these bags for up to 42 days.

Blood cultures of both bags were negative for bacterial growth throughout the storage period. The importance of the microbiological evaluation is determined by its role in the human blood banks, as it ensures the quality of the transfused blood, being one of the parameters rigorously evaluated and followed by human blood banks, and it also proves that the changes observed in stored blood were not due to bacterial growth (NUNES NETO et al., 2018).

\section{CONCLUSION}

Goat whole blood stored for 42 days remains viable for therapeutic use, though some important variables undergo certain changes. Goat blood seems to be more resistant to alteration during storage in blood bags compared to other species blood, like sheep blood, with limited hemolysis occurring after 42 days of storage. Comparative analysis between the two types of bags reveals similar results for the vast majority of studied variables. Thus, the CPDA-1 bag can be considered the better choice for use in goat blood storage due to its lower commercial value.

\section{ACKNOWLEDGEMENTS}

AHHM thanks Conselho Nacional de Desenvolvimento Científico e Tecnológico (CNPq) for the research productivity grant. The authors are grateful to Clara Satsuki Mori for her help with laboratory analysis.

\section{ETHICS AND BIOSAFETY COMMITTEE}

This study was approved by the Animal Use Bioethics Commission (CEUA) of the Universidade Federal Rural do Semiárido (UFERSA) (Protocol - 59/2013).

\section{DECLARATION OF CONFLICT OF INTERESTS}

The authors declare no conflict of interest. The founding sponsors had no role in the design of the study; in the 
collection, analyses, or interpretation of data; in the writing of the manuscript, and in the decision to publish the results.

\section{CONTRIBUTION OF AUTHORS}

MDT, IOB, RSS, PRF, JSG and FLCO conducted the experiment and all laboratory analysis, data analysis and writing of the work. AHHM, ELO, RABJ outlined the study, supervised the activities, analyzed the data, and reviewed the manuscript.

\section{REFERENCES}

ANVISA. RESOLUÇÃO-RDC/ANVISA no 153, de 14 de junho de 2004. [S.1.]: [s.n.], 2004. Available from: $<$ http://www. sbpc.org.br/upload/noticias_gerais/320100416113458.pdf $>$. Accessed: Jun. 42019.

ARAÚJO, M. R. E. Hemocultura: Recomendações de coleta, processamento e interpretação dos resultados Coleta de hemoculturas. Journal Infect Control, 2012. v.1, n.1, p.8-19. Available from: <http://www.iqg.com.br/pbsp/img up/01355393320.pdf>.

ARGOLO, E. P. et al. Clinical responses to acute blood loss in goats. Semina: Ciencias Agrarias, 2018. v. 39, n. 2.

BALCOMB, C.; FOSTER, D. Update on the Use of Blood and Blood Products in Ruminants. Veterinary Clinics of North America: Food Animal Practice, Jul. 2014. v.30, n.2, p.455-474. Available from: <http://www.ncbi.nlm.nih.gov/ pubmed/24980732>. Accessed: Jun. 262017.

BARROS, I. De O. Avaliação da conservação do sangue total de asininos (Equus asinus) acondicionado em bolsas CPDA-1 E CPD/SAG-M. [S.1.]: Universidade Federal Rural do Semiárido, 2011.

CARLSON, G. P. Chapter 18 - Fluid, Electrolyte, and Acid-Base Balance. Clinical Biochemistry of Domestic Animals. [S.1.]: [s.n.], 1997, p. 485-516.

CORSI, R. et al. Cytokine concentration in stored canine erythrocyte concentrates. Journal of Veterinary Emergency and Critical Care, May, 2014. v.24, n.3, p.259-263. Available from: $<$ http://www.ncbi.nlm.nih.gov/pubmed/24697952>. Accessed Mar. 29, 2019.

COSTA JÚNIOR, J. et al. Parâmetros bioquímicos e hemogasométricos do sangue total canino armazenado em bolsas plásticas contendo CPDA-1 e CPD/SAG-M. Ciência Rural, Apr. 2008. v.38, n.2, p.378-383. Available from: $<$ http:// www.scielo.br/scielo.php? script $=$ sci_arttext\&pid $=\mathrm{S} 0103$ $84782008000200013 \& \operatorname{lng}=$ pt\&tlng $=$ pt $>$. Accessed: Jun. 13, 2018.

COSTA, V. M. M.; SIMÕES, S. V.D.; RIET-CORREA, F. Controle das parasitoses gastrintestinais em ovinos e caprinos na região semiárida do Nordeste do Brasil. Pesquisa Veterinária Brasileira, Jan. 2011. v.31, n.1, p. 65-71. Available from: $<$ http://www.scielo. br/scielo.php?script=sci_arttext\&pid=S0100-736X201100010001 $0 \& \operatorname{lng}=\mathrm{pt} \& \mathrm{t} \operatorname{lng}=\mathrm{pt}>$. Accessed: Mar. 29, 2019.

FONSECA, N. B. S. et al. Biochemical responses, blood gas, oxidative stress and lipid peroxidation of goats transfused with fresh or stored whole homologous blood. Pesquisa Veterinária Brasileira, Nov. 2018. v.38, n.11, p.2070-2079.
Available from: $<$ http://www.scielo.br/scielo.php?script $=$ sci arttext\&pid=S0100-736X2018001102070\&lng=en\&tlng=en $>$. Accessed: Mar. 29, 2019.

HESS, J. R. Red cell storage. Journal of Proteomics, 3 Jan. 2010. v.73, n.3, p.368-373. Available from: <http://www.ncbi.nlm.nih. gov/pubmed/19914410>. Accessed: Jun. 13, 2018.

HESS, J. R.; GREENWALT, T. G. Storage of red blood cells: New approaches. Transfusion Medicine Reviews, out. 2002. v.16, n.4, p.283-295. Available from: <http://www.ncbi.nlm.nih.gov/ pubmed/12415514>. Accessed: Jun. 13, 2018.

IBGE. Produção da pecuária municipal. 47. ed. Rio de Janeiro: [s.n.], 2015.

KANEKO, J. J.; HARVEY, J. W.; BRUSS, M. Clinical biochemistry of domestic animals. [S.l.]: Elsevier/Academic Press, 2008.

KORZUN, W. J.; MILLER, W. G. Sodium and potassium. In: KAPLAN, L. A.; PESCE, A. J. (Org.). Clinical chemistry: theory, analysis, correlation. 5. ed. Saint Louis: Mosby/Elsevier, 2010, p. 1176.

LACERDA, L. A. et al. Effects of four additive solutions on canine leukoreduced red cell concentrate quality during storage. Veterinary Clinical Pathology, Sept. 2014. v.43, n.3, p.362-370. Available from: <http://www.ncbi.nlm.nih.gov/ pubmed/25135622>. Accessed: Mar. 29, 2019.

LANEVSCHI, A.; WARDROP, K J. Principles of transfusion medicine in small animals. Canadian Veterinary Journal, Jun. 2001. v.42, n.6, p.447-454. Available from: <http://www.ncbi.nlm. nih.gov/pubmed/11424576>. Accessed: Jun. 13, 2018.

MARCHI, M. N. A. De et al. Skin antisepsis protocols for the collection of blood from donor dogs. Ciência Rural, 10 May, 2018. v.48, n.5. Available from: <http://www.scielo.br/scielo. php?script $=$ Sci_arttext\&pid=S0103-84782018000500601\&lng=en \&tlng=en>. Accessed: Apr. 3, 2019.

MCMICHAEL, M.A. et al. Effect of Leukoreduction on Transfusion-Induced Inflammation in Dogs. Journal of Veterinary Internal Medicine, Sept. 2010. v.24, n.5, p.1131-1137. Available from: $\quad<$ http://www.ncbi.nlm.nih.gov/pubmed/20666981>. Accessed: Jun. 13, 2018.

MUDGE, M. C. et al. Comparison of 4 Blood Storage Methods in a Protocol for Equine Pre-operative Autologous Donation. Veterinary Surgery, Sept. 2004. v.33, n.5, p.475-486. Available from: $\quad<$ http://www.ncbi.nlm.nih.gov/pubmed/15362986>. Accessed: Mar. 29, 2019.

NIINISTO, K.; RAEKALLIO, M.; SANKARI, S. Storage of equine red blood cells as a concentrate. 2008. v.176, p.227-231.

NUNES NETO, O. G. et al. Hematological changes in buffalo (Bubalus bubalis) whole blood stored in CPDA-1 or CPD/SAG-M plastic bags. Buffalo Bulletin, 2018. v.37, n.3, p.403-410.

REICHMANN, P.; DEARO, A. C. O. Blood and blood component transfusion in large animals. Semina: Ciências Agrárias, Feb. 2001. v.22, n.2, p.223-228. Available from: <http://www.uel.br/ revistas/uel/index.php/semagrarias/article/view/2056>. 
RIBEIRO FILHO, J. D. et al. Alterações bioquímicas de sangue bovino durante a conservação por 35 dias, em frascos de vidro com ACD e bolsas plásticas com CPDA-1. Veterinária e Zootecnia, 1994. v.5, p.97-103.

SOUSA, R.S. et al. Lesoes de armazenamento durante a conservacao de sangue nas diferentes especies: uma revisao. Acta Veterinaria Brasilica, 2012a. v.6, n.2, p.68-79.

SOUSA, Rejane S. et al. Evaluation of hematologic, Blood gas, And select biochemical variables in ovine whole blood stored in CPDA-1 bags. Veterinary Clinical Pathology, mar. 2013. v.42, n.1, p.27-30. Disponível em: <http://www.ncbi.nlm.nih.gov/ pubmed/23278354>. Accessed: Jun. 13, 2018.

SOUSA, Rejane Santos et al. Clinical, haematological and biochemical responses of sheep undergoing autologous blood transfusion. BMC veterinary research, 20 jan. 2012b. v.8, n.1, p.61. Available from: <http://www.pubmedcentral.nih.gov/ articlerender.fcgi? artid $=3416721 \&$ tool $=$ pmcentrez\&rendertype $=\mathrm{a}$ bstract>. Accessed: Jan. 29, 2014.

WEISS, D. J.; WARDROP, K. Jane.; WEISS, D. J. Schalm's Veterinary Hematology. [S.1.]: Wiley, 2011. 